\title{
Assessing the chemical contamination dynamics in a mixed land use stream system
}

\author{
Sonne, Anne Thobo; McKnight, Ursula S.; Rønde, Vinni; Bjerg, Poul Løgstrup
}

Published in:

Water Research

Link to article, DOI:

10.1016/j.watres.2017.08.031

Publication date:

2017

Document Version

Peer reviewed version

Link back to DTU Orbit

Citation (APA):

Sonne, A. T., McKnight, U. S., Rønde, V., \& Bjerg, P. L. (2017). Assessing the chemical contamination dynamics in a mixed land use stream system. Water Research, 125, 141-151. https://doi.org/10.1016/j.watres.2017.08.031

\section{General rights}

Copyright and moral rights for the publications made accessible in the public portal are retained by the authors and/or other copyright owners and it is a condition of accessing publications that users recognise and abide by the legal requirements associated with these rights.

- Users may download and print one copy of any publication from the public portal for the purpose of private study or research.

- You may not further distribute the material or use it for any profit-making activity or commercial gain

- You may freely distribute the URL identifying the publication in the public portal 


\section{Accepted Manuscript}

Assessing the chemical contamination dynamics in a mixed land use stream system

Anne Th. Sonne, Ursula S. McKnight, Vinni Rønde, Poul L. Bjerg

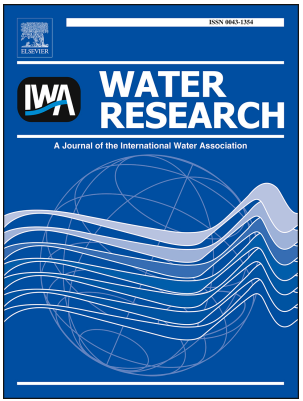

PII:

S0043-1354(17)30693-0

DOI:

10.1016/j.watres.2017.08.031

Reference:

WR 13154

To appear in: Water Research

Received Date: 7 April 2017

Revised Date: 10 August 2017

Accepted Date: 14 August 2017

Please cite this article as: Sonne, A.T., McKnight, U.S., Rønde, V., Bjerg, P.L., Assessing the chemical contamination dynamics in a mixed land use stream system, Water Research (2017), doi: 10.1016/ j.watres.2017.08.031.

This is a PDF file of an unedited manuscript that has been accepted for publication. As a service to our customers we are providing this early version of the manuscript. The manuscript will undergo copyediting, typesetting, and review of the resulting proof before it is published in its final form. Please note that during the production process errors may be discovered which could affect the content, and all legal disclaimers that apply to the journal pertain. 


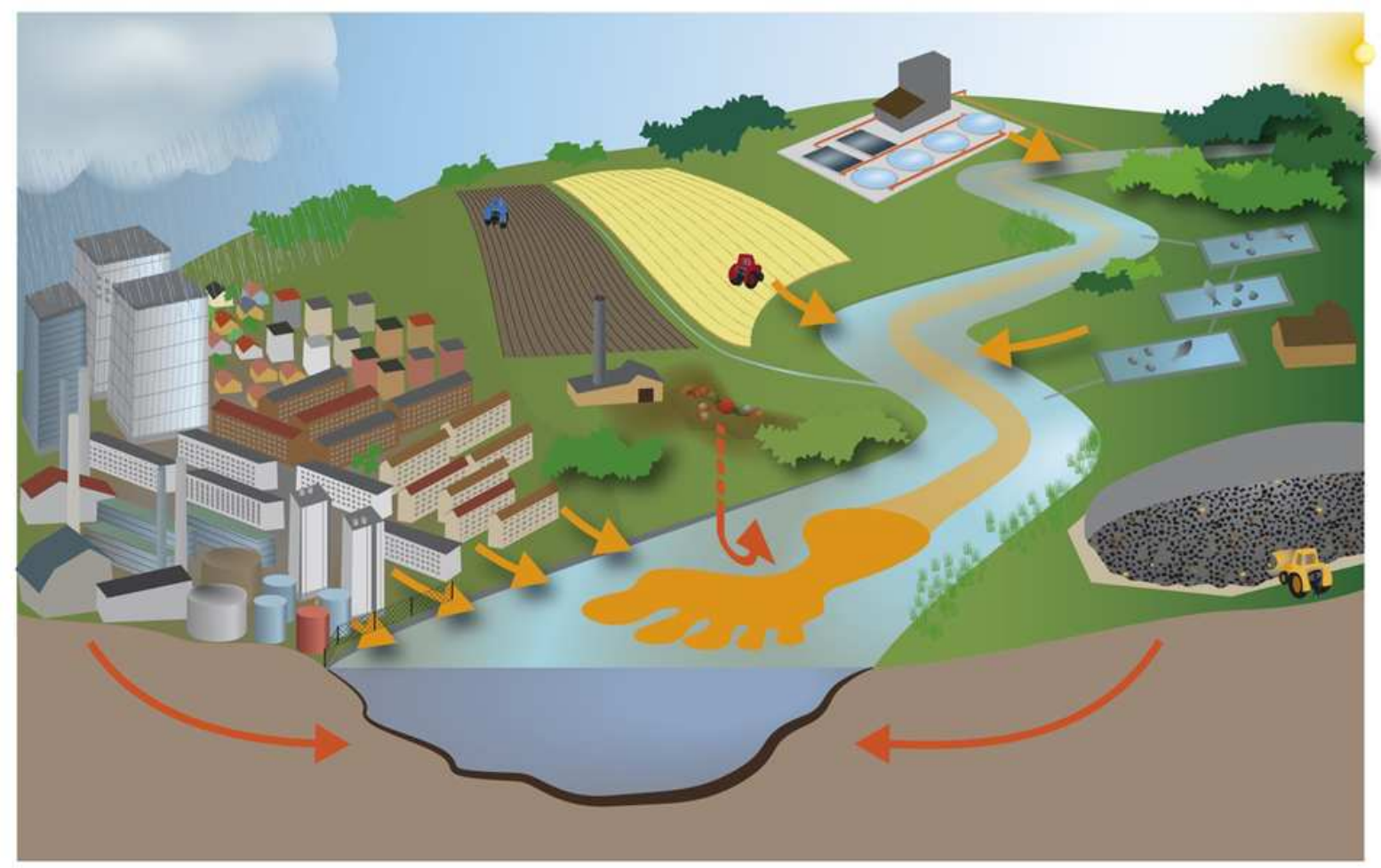



system

3 Anne Th. Sonne ${ }^{1 *}$, Ursula S. McKnight ${ }^{1}$, Vinni Rønde ${ }^{1}$, Poul L. Bjerg ${ }^{1}$

$4 \quad{ }^{1}$ Department of Environmental Engineering, Technical University of Denmark, Bygningstorvet 115, 2800

$5 \quad$ Kgs. Lyngby, Denmark

$6 \quad *$ Corresponding author: ants@env.dtu.dk

7

$8 \quad$ Submitted March 2017

9

Key words: Risk assessment; Multiple chemical stressors; Mixed land use stream systems; Contaminated

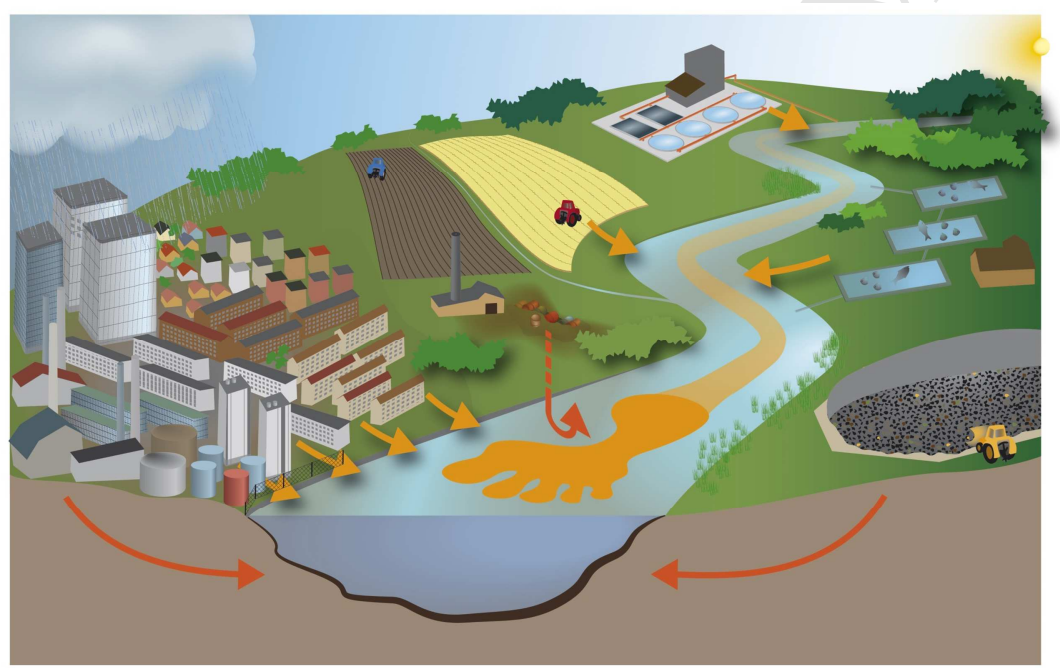


surface water concentrations, where the dominant focus has been on general water quality and the risk for eutrophication. Mixed land use stream systems, comprising urban areas and agricultural production, are challenging to assess with multiple chemical stressors impacting stream corridors. New approaches are urgently needed for identifying relevant sources, pathways and potential impacts for implementation of suitable source management and remedial measures. We developed a method for risk assessing chemical stressors in these systems and applied the approach to a $16-\mathrm{km}$ groundwater-fed stream corridor (Grindsted, Denmark). Three methods were combined: (i) instream contaminant mass discharge for source quantification, (ii) Toxic Units and (iii) environmental standards. An evaluation of the chemical quality of all three stream compartments stream water, hyporheic zone, streambed sediment - made it possible to link chemical stressors to their respective sources and obtain new knowledge about source composition and origin. Moreover, toxic unit estimation and comparison to environmental standards revealed the stream water quality was substantially impaired by both geogenic and diffuse anthropogenic sources of metals along the entire corridor, while the streambed was less impacted. Quantification of the contaminant mass discharge originating from a former pharmaceutical factory revealed that several $100 \mathrm{kgs}$ of chlorinated ethenes and pharmaceutical compounds discharge into the stream every year. The strongly reduced redox conditions in the plume result in high concentrations of dissolved iron and additionally release arsenic, generating the complex contaminant mixture found in the narrow discharge zone. The fingerprint of the plume was observed in the stream several km downgradient, while nutrients, inorganics and pesticides played a minor role for the stream health. The results emphasize future investigations should include multiple compounds and stream compartments, and highlight the need for holistic approaches when risk assessing these dynamic systems. 


\section{Introduction}

The increasing modification in land use, land cover and water management driven by urban

expansion and increased agricultural production have created multiple chemical stressors impacting surface water bodies on a global scale (Davis et al., 2010; Yu et al., 2014). The impairments are especially noticeable in freshwater stream systems, which are highly connected to their landscape via their draining systems (Fausch et al., 2010). The growing understanding of the complexity inherent in mixed land use stream systems (Ding et al., 2016 Stutter et al., 2007) has shifted the focus towards risk assessment approaches at the catchment scale, as opposed to controlling isolated contamination events. It is still a major challenge in practice however, to quantify relevant sources, pathways and chemical stressors impacting stream water for use in determining essential source management and remedial measures.

Determining the chemical status of a stream is relatively straight-forward from a legislative perspective, as it has been defined in part by a set of (European) environmental quality standards (EQS) for priority substances in the stream water (EQS Directive (2008/105/EC)), and in part by legislation derived within the individual Member State countries (e.g. Danish EPA, 2010). In reality, however, determining where to collect suitable field data for comparison with EQS values is complicated, especially in these systems. Specifically, the high temporal and spatial variations of the contamination dynamics create a complex picture where the distribution of contaminants will depend on a number of factors (e.g. hydrological system, physico-chemical properties, biogeochemical processes) leading to diverse impacts within different stream compartments, i.e. stream water, hyporheic zone or bed sediments. The transport, fate and toxicity of contaminants in such systems are thus a challenge to assess, so despite intensive research spanning decades (Schwarzenbach et al., 2006; Kuzmanovic et al., 2016), approaches for conducting proper risk assessments in such environments are still being sought after.

The contaminant mass discharge (CMD) approach seems promising for the quantification of anthropogenic point source-related pollutants, such as contaminated sites (Newell et al., 2011) or wastewater outlets into streams. It can be used to support an overall evaluation of the magnitude and importance of these various sources. Furthermore, measurements of the contaminants in stream 
water can be used to quantify CMD from a source, as shown by Aisopou et al. (2015). However, this approach cannot take changes due to attenuation and transformation processes in e.g. the hyporheic zone into account, potentially leading to underestimations. It is also more limited for contaminants with a higher tendency to sorb, as the concentrations often will be very low in stream water.

It is not possible to make similar mass discharge estimations for diffuse sources such as trace elements or metals coming from anthropogenic and geogenic sources. Here, the source function is related to the geological settings and often worsened by acidification or changes in the prevailing redox conditions (Edmunds et al., 1992; Cozzarelli et al., 2016). The understanding and distinction between anthropogenic and geogenic sources of metals thus requires insight of the governing biogeochemical processes in the groundwater, hyporheic zone and stream, while the geogenic source is often inaccessible for remedial actions.

Toxic units (TU) is a commonly used screening tool providing an initial overview of the potential ecological risk, where dissolved-phase chemical concentrations are used as a proxy for environmental effects based on the use of toxicity values (Rasmussen et al., 2015, Tomlin, 2001). Application of this tool makes it possible to assess the water quality in the stream water (SW), hyporheic zone (HZ) and bed sediment (BS) calculated as pore water (PW). Notably, laboratoryderived toxicity tests cannot reproduce the complexity of the receiving environment, nor can they provide insight on the long-term impact of continuous low-dose contamination (Beketov and Liess, 2012). Nevertheless, it can be used to provide a uniform assessment of all identified chemical stressors potentially impacting the stream environment, and is thus in line with the requirements of the European Water Framework Directive (WFD) (EC, 2017).

The objectives of this paper are to develop and apply a methodology for holistically assessing the quality of a mixed land use stream system at the catchment scale. In order to more accurately assess the origins and potential toxicity of chemical stressors detected in the various compartments along a stream corridor, we suggest to combine three approaches: (i) in-stream CMD, (ii) TU and (iii) EQS for SW, BS (US EPA, 2006), and general water chemistry parameters (DCEE, 2012). The 
methodology is applied to Grindsted stream, located in western Denmark. The chemical quality of the SW, HZ and BS was determined, allowing contaminants of concern to be linked to their respective sources. Then for anthropogenic point source-related compounds, their CMD into the stream was estimated, followed by an assessment of the in-stream fate specifically for the organic xenobiotic compounds. Finally, in order to identify key sources and risk drivers, a risk assessment was conducted by combining calculations of predicted ecotoxicity within the CMD framework.

\section{Material and methods}

\subsection{Grindsted stream study site and potential contaminant sources}

The study site comprises a 16-km corridor along Grindsted stream with a catchment size of ca. $200 \mathrm{~km}^{2}$, representing a typical Danish landscape with diverse land use activities and contaminant sources (Fig. 1). Grindsted stream is generally groundwater-fed with a median flow of $2000 \mathrm{~L} / \mathrm{s}$ (Nielsen et al., 2014) and is naturally meandering with only few modifications. The stream depth ranges from 1-2.5 $\mathrm{m}$ and the width from 8-12 $\mathrm{m}$. The $80 \mathrm{~m}$ thick upper aquifer is unconfined and hydrologically connected to the stream. The geology is characterized by Quaternary sand formations (10-15 meter below ground surface, mbgs), underlain by Tertiary sand formations (Heron et al., 1998). Beneath this, a thick and extended clay layer comprises the regional aquitard. Groundwater chemistry of the noncalcareous sandy aquifer indicates that there are increased levels of dissolved trace metals at shallow depths, including aluminum and nickel, due to groundwater acidification (Kjøller et al., 2004).

Potential contaminant sources relevant to the stream include agricultural activities (comprising $54 \%$ of the catchment), a wastewater treatment plant (WWTP), two fish farms and diverse urban point and diffuse sources coming from Grindsted - a town with ca. 10,000 inhabitants (12\% land use). Grindsted WWTP (Fig. 1) is a potential point source for nutrients and salts to the stream in the lower catchment. In 2014 it discharged 11 and 1.5 tonnes of total-N and total-P, respectively, with an average discharge of $70 \mathrm{~L} / \mathrm{s}$ to the stream (Billund Vand A/S, 2016). Other industrial discharges (of cooling- and wastewater) come from DuPont factory, with an average of $6 \mathrm{~L} / \mathrm{s}$ in 2014 containing 316, 0.8 and 0.2 tonnes of chloride, total-N and total-P, respectively (MEF, 2016). The 
two fish farms, located in the upper catchment, are potential sources for both nutrients and pharmaceuticals (DANMAP, 2005).CCEPTED MANUSCRIPT

Moreover, two large-scale contaminated sites are located within $2 \mathrm{~km}$ of the stream: a pharmaceutical factory (in operation from 1914-1999), and an unlined, abandoned municipal landfill that closed in 1977 (Kjeldsen et al., 1998). Previous studies have shown that the groundwater beneath and downstream of both sites are contaminated by multiple chemicals, including pharmaceuticals (e.g. sulfonamides, barbiturates) and petroleum hydrocarbons (benzene, toluene, ethylbenzene, m-/p-/o-xylenes, i.e. BTEX) (Kjeldsen et al., 1998; Holm et al., 1995; Rügge et al., 1995). The groundwater plume from the factory site also contains high concentrations of chlorinated ethenes: tetrachloroethylene (PCE) and trichloroethylene (TCE), and their degradation products cis-1,2-dichloroethylene (cis-DCE) and vinyl chloride (VC) (Hunkeler et al., 2011). The contaminant groundwater plume has been delineated from the factory site and the flow is towards the stream (Rasmussen et al., 2016; Balbarini et al., 2017). The local and regional flow direction of the landfill plume is not well understood, and it is unclear whether it enters the stream. In addition to these and other smaller-scale contaminated sites located along the stream corridor, other urban sources consist of storm water runoff, traffic (incl. road salt for deicing purposes) and biocide applications (weed control; paint) in residential and public areas. 


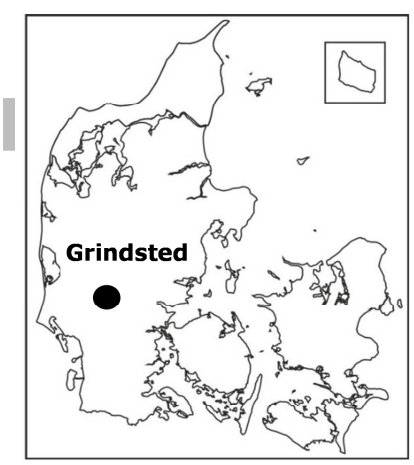

Station 1-12

(SW, HZ, Sediment)

Forrest

Long term A-H

Grindsted urban area

Roads, major

(SW)

Agriculture

†WWTP

Stream gauge

पind Fish farm

Factory site

Landfill

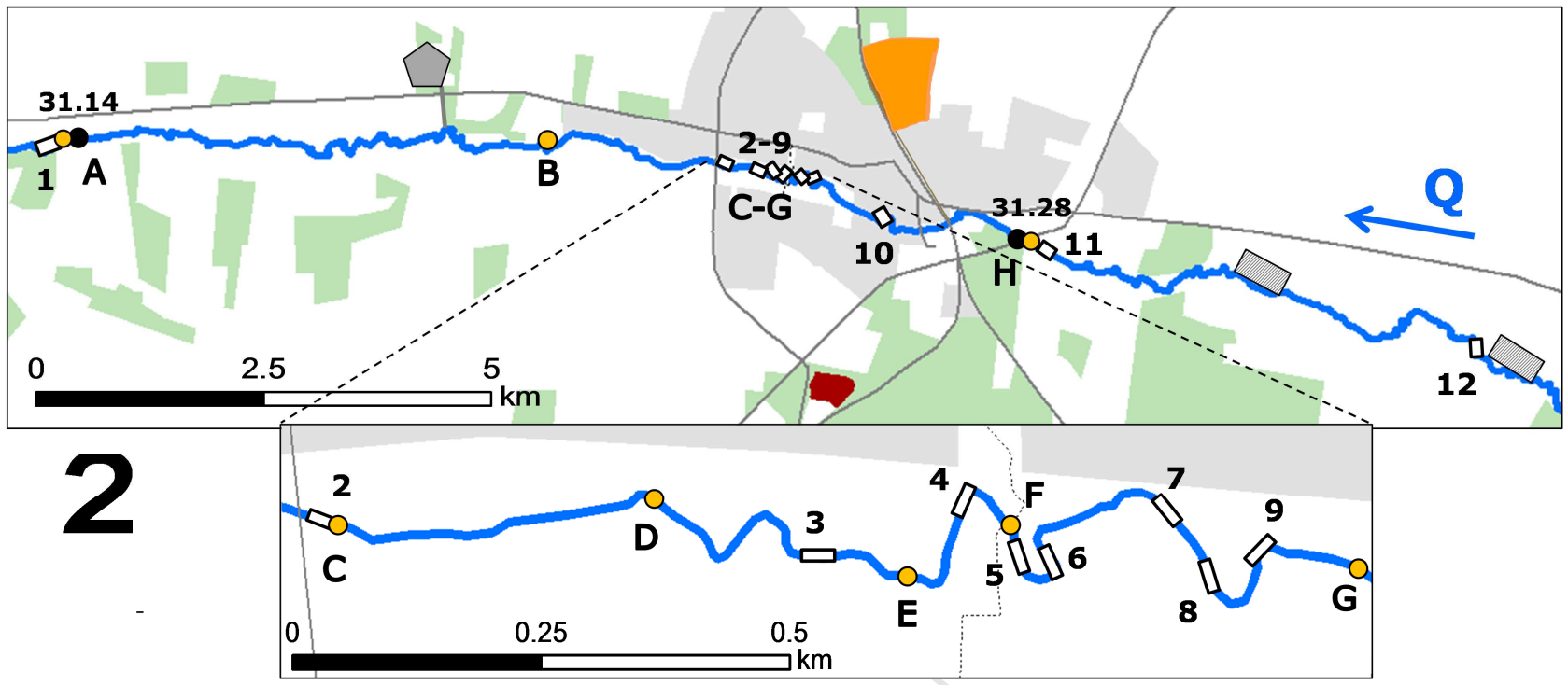

Fig. 1: Land use distribution along the investigated stream corridor, including Grindsted factory, Grindsted landfill, WWTP, and the two fish farms (note the sizes are magnified). The stream flow direction, Q, is illustrated with a blue arrow. The two online monitoring stream gauges, 31.28 and 31.14, are shown with black dots. Locations are also shown for the (i) twelve sampling stations, investigated in Apr 2014 (open rectangles labelled 1-12), and the (ii) eight long-term stations, monitored from Aug 2012 to Mar 2015 (yellow circles, labelled A-H).

\subsection{Investigation strategy}

In order to assess and link probable chemical impacts to their respective sources in the catchment, samples were taken from the SW, HZ (40-60 cm depth) and BS. Twelve sampling stations (1-12) were strategically placed in Apr 2014 (Fig. 1). Selected stations were re-visited in Aug 2014 (i.e. 2, 4, 6, 8, 10). The density and number of sampling stations were higher in the central part of the stream corridor, where urban sources and inflow of contaminated groundwater from the factory site were expected. Particular attention was given to compounds measured in previous surveys of the stream and in plume constituents from the factory and landfill sites (Rasmussen et al., 2016; Holm et al., 1995; Rügge et al., 1995).

\subsection{Sampling and analytes}

In Apr 2014, one SW sample was taken in the middle of the stream, in the middle of the water column at each of the twelve stations. Water samples from the HZ were collected at stations 4, 6 
and 8 in the middle of the stream. Sampling of the upper $5 \mathrm{~cm}$ of the BS was conducted at all stations. 36 subsamples were taken evenly distributed across each station and subsequently pooled into one sample. In Aug 2014, the 5 selected stations were then re-investigated, focusing on a smaller area of the initial $50 \mathrm{~m}$ station, i.e. $5 \times 5 \mathrm{~m}^{2}$. Note that at station 4 , two sub-stations were placed: one in the upstream part of the station (4US) and one downstream (4DS). SW, HZ and BS samples were collected at all stations.

SW and HZ samples were analyzed for general water chemistry, selected trace metals and a range of xenobiotic organic compounds (Table S1). The BS was analyzed for total organic carbon (TOC), selected trace metals, pesticides and associated metabolites (Table S1). Furthermore, the grain size distribution was determined. Hydrophilic chlorinated ethenes, BTEX and naphthalene (BTEX,N) and the pharmaceutical compounds were omitted from the BS analysis, as they were expected to be below detection limits (Table S2).

\subsection{Monitoring of stream flow and long-term water quality}

Seasonal variation of the stream flow (Q) from summer 2012 to spring 2015 was quantified by daily monitoring of the stream water level (h) at the two gauging stations $(31.28,31.14$; Figures 1 , S1). To establish a Q-h relationship, 26 independent manual measurements of $h$ and $Q$ were executed at both stream gauges. Additional stream flow measurements were used to describe the variation along the investigated stream corridor (Nielsen et al., 2014; Rasmussen et al., 2016) including manual measurements at five stations in this study $(1,2,4,9,11$; Table S3).

Seven sampling campaigns were carried out to investigate seasonal variations in SW quality (Aug 2012, Apr, May, June, Aug and Oct 2014, Mar 2015) and support the analysis of the in-stream contaminant fate at the eight long-term sampling points (A-H, Fig. 1). Chlorinated ethenes and BTEX,N were included in all seven sampling campaigns, while the pharmaceutical compounds were included in three campaigns (Aug 2012, Apr and Aug 2014). In Oct 2014 and Mar 2015, ethene and ethane were included; compound-specific stable carbon isotope analyses of cis-DCE and VC were conducted in Oct 2014. 


\subsubsection{General water chemistry ACCEPTED MANUSCRIPT}

General water chemistry parameters were measured at all sampling sites (Tables S4-5). Field measurements of $\mathrm{pH}$, electrical conductivity (EC) and dissolved oxygen were conducted by electrodes (WTW Multi 3420). Biological oxygen demand (BOD, ortho-phosphate and ammonium$\mathrm{N}$ in SW were analysed following the European Standard methods (DS/EN 1899-1999, DS/EN 1189-1997, DS 11732-2005, respectively). Total-N and total-P were measured using the Kjeldahl-N method and Danish standard DS-291. The samples to be analyzed for inorganic anions (chloride, bromide, dissolved nitrate-N, sulphate-S) were filtered $(0.45 \mu \mathrm{m})$ and stored on dry ice in the field until analysis. The samples were analyzed using ion chromatography, Dionex ICS-1500, with an Ion Pac AS 14A mm Column (P/N 056904) and Ion Pac AG14 "Guard" Column in combination with an anion suppressor, Metrohm 833 IC. Samples to be analyzed for NVOC were filtered (0.45 $\mu \mathrm{m})$ and preserved with $4 \mathrm{M}$ phosphoric acid (17 w/w\% to $\mathrm{pH} 2)$ and analyzed by oxidation with catalytic combustion (TOC 5000A, Shimadzu, ASI-5000 autosampler).

\subsubsection{Xenobiotic compounds and metals in water samples}

Samples for the analysis of chlorinated ethenes and degradation products, and BTEX,N were analyzed following the procedure according to McKnight et al. (2012; Tables S6-7). Compoundspecific stable carbon isotope analysis for chlorinated ethenes was done according to Hunkeler et al. (2011). Analyses of pesticides and associated metabolites (Tables S8-9), as well as pharmaceutical compounds (e.g. sulfonamides, barbiturates; Tables S6-7) were conducted by ALS Denmark A/S. Samples for the analysis of metals were filtered $(0.2 \mu \mathrm{m})$ and preserved with $1 \% \mathrm{v} / \mathrm{v}$ nitric acid in the field and analyzed using Inductively Coupled Plasma-Optical Emission Spectrometry (ICPOES, MPX Vista Axial, Auto sampler SPS3; Tables S10-11).

\subsubsection{Sediment analysis}

TOC was measured by initially homogenizing and acidifying the BS sample with phosphoric acid $\left(\mathrm{H}_{3} \mathrm{PO}_{4}\right)$ before it was analyzed on a LECO Induction Furnace CS-200. The grain size distribution was determined according to Heron et al. (1998; Tables S12-13). Metal concentrations, 
except mercury, were determined according to US EPA standard 3051A, and analyzed using ICPOES. Mercury was measured byCALS Denmark A/S. Pesticide and associated metabolite concentrations were determined by the Swedish University of Agriculture (Jansson and Krueger, 2010).

\subsection{Data analysis methods}

\subsubsection{Calculation of in-stream contaminant mass discharge and dilution factors}

Using a simple mass balance and plug flow interpretation to describe the mixing and transport of a discharged compound to a stream, an estimate of the CMD can be derived (for details see Aisopou et al., 2015):

$C M D=C_{\text {mix }} \cdot Q_{\text {mix }}$

where $C M D$ is the total mass discharge of the compound at the point of fully mixed conditions in the stream, $C_{m i x}$ is the SW concentration at the point of fully mixed conditions and $Q_{m i x}$ the flow of the stream at the mixing point.

A linear approach following the course of the stream was employed to estimate the stream flow, $Q$, at a given point between the two stream gauges. A comparison of the stream flow at the two points showed a maximum variation of only $7.5 \%$ over time (for details see Table S14).

A dilution factor for stream stretches of interest was furthermore calculated using manual flow measurements (Table S3). These were estimated using the most upstream measurement as a reference (dilution equals 1.0) for downstream reach calculations. The estimated factors were employed to determine the degree of dilution for organic xenobiotic compounds in the SW.

\subsubsection{Calculation of predicted ecotoxicity}

The toxicological potential for dissolved-phase contaminants was estimated using the TU approach, with Daphnia magna as the benchmark organism following Tomlin (2001): $T U=C_{i} /$ $L C 5 O_{i}$, where $C_{i}$ is the measured concentration of compound $i$, and $L C 5 O_{i}$ is the corresponding acute 48-h 50\% mortality value for D. magna exposed to compound $i$ (Table S1). The TU for all detected compounds was estimated for the SW, HZ and BS compartments. Based on the linear dilution approach, the $\mathrm{HZ}$ concentrations for stations 1, 2, 3, 5, 7, 9, 10 and 12 in Apr 2014 were assumed to 
be equal to SW concentrations if no increment was observed in the downstream SW. Estimations of BS toxicity for sediment-bound compounds were calculated by converting measured bulk sediment concentrations to PW according to equilibrium-partitioning theory (Di Toro et al., 1991; van der Kooij et al., 1991; Tables S12-13).

We calculated the sum of all TUs for each compartment ( $\Sigma T U$, Table 2), for each of five detected compound groups (defined as: chlorinated ethenes, BTEX,N, metals, pesticides, pharmaceuticals), which is in line with the principle of screening-level risk assessments. The more conservative TU threshold value, $\mathrm{TU} \geq-3.0$, was used for determining impact levels associated with acute observed effects on macroinvertebrate communities in the field (Liess et al., 2008).

\section{Results and discussion}

\subsection{Connecting spatial contaminant discharges to sources}

\subsubsection{Stream flow, general water quality and nutrients}

The stream flow monitored between June 2012 and Mar 2015 varied from 1500-4100 L/s at the central gauge 31.28 (Fig. 1), with an average increase of $855 \mathrm{~L} / \mathrm{s}$ to the downstream gauge 31.14 (Fig. 1, Fig. S1). The oxygen level and biological oxygen demand (BOD) in the SW were equally stable throughout the stream corridor with values above $9 \mathrm{mg} \mathrm{O} / \mathrm{L}$ and below $1.4 \mathrm{mg} \mathrm{BOD} / \mathrm{L}$ (see Tables S4-5 for general SW quality parameters). Surprisingly, only a small nitrogen-enrichment and no phosphorous influence were observed in the SW despite that agriculture is the main land use in the catchment. The nitrogen input from the WWTP was also minor, contributing only $6 \%$ to the total nitrogen increase along the entire stretch (Figure 1) (Table S15). Although nutrients are viewed as key components for SW quality, their importance for Grindsted stream is minor and will not be discussed further.

\subsubsection{Macro-ions}

A significant increase of chloride, sodium and EC was observed in the urban upstream SW (between stations 11 and 10) in Apr 2014 (Fig. 2 A-B, Table S4). A similar pattern was detected in Aug 2014 and in previous studies (Table S5; Rasmussen et al., 2016; Petersen, 2012), while the 
268 cations calcium, magnesium and potassium seemed stable. A calculation of the chloride input 269 coming from industrial discharges (316 tonnes/yr) compared to the estimated increase at station 10 270 of 1,192 tonnes/yr showed that it was only responsible for $24 \%$ of the chloride increment (Fig. 1, 271 Tables 1, S15). This particular $1.5 \mathrm{~km}$ stream stretch drains an area where three larger roads cross or 272 run close to the watercourse, indicating road salting for deicing purposes as a potential source as 273 reported in other studies (Cooper et al., 2014). The consistently high salt content at station 10 in 274 both Apr and Aug (and in previous campaigns) suggests groundwater as the main pathway, rather 275 than seasonal run-off to the stream during winter. 

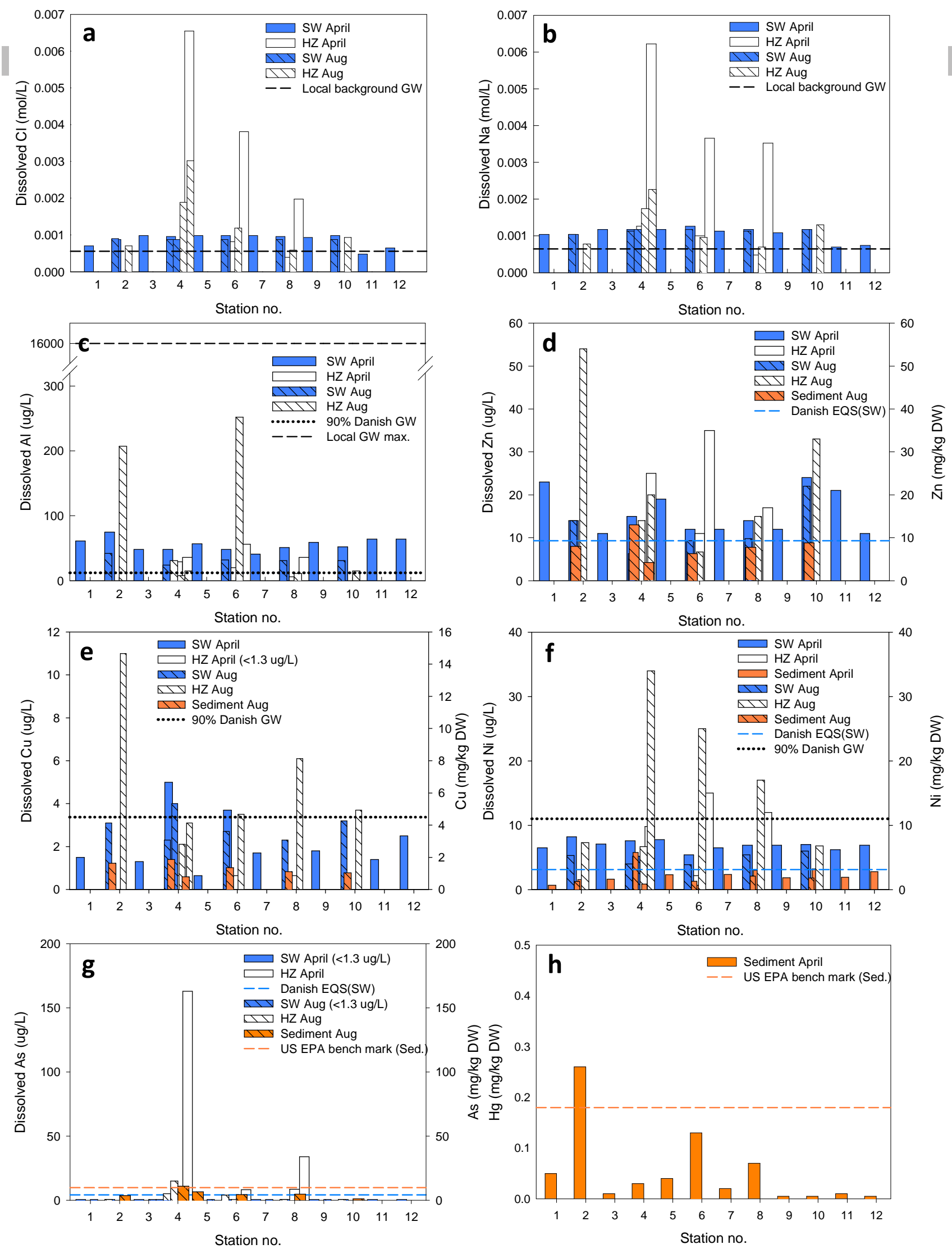

Fig. 2: Spatial occurrence of (a-b) macro-ions: $\mathrm{Cl}, \mathrm{Na}$ (shown in molar concentration), and (c-g) trace metals: $\mathrm{Al}, \mathrm{As}, \mathrm{Cu}, \mathrm{Ni}$ and $\mathrm{Zn}$ in $\mathrm{SW}, \mathrm{HZ}$ and the upper $5 \mathrm{~cm}$ of the BS. The sediment content is shown for (h) $\mathrm{Hg}$. Note the sub-scale can differ from subfigure to subfigure. The local background level of $\mathrm{Cl}$ and $\mathrm{Na}$ are shown for groundwater beneath farmland in the area according to Nielsen et al. (1998), and Al beneath grassland by Kjøller et al. (2004). The Danish Cu EQS(freshwater) ranges from 1-12 $\mu \mathrm{g} / \mathrm{L}$ (Table 2). The US EPA benchmark (sediment) values of $\mathrm{Cu}, \mathrm{Ni}$ and $\mathrm{Zn}$ are respectively $31.6 \mathrm{mg} \mathrm{Cu} / \mathrm{kg}$ DW, $460 \mathrm{mg} \mathrm{Ni} / \mathrm{kg} \mathrm{DW}$ and $121 \mathrm{mg} \mathrm{Zn} / \mathrm{kg} \mathrm{DW}$, well above the detected concentrations and are therefore not included. 
Table 1: Point and diffuse sources identified along Grindsted stream coming from anthropogenic and geogenic origins, including specific chemical stressors, estimated CMD, expected pathway to the stream and presumed duration for the discharge. Estimations are based on the SW concentrations measured in Apr 2014 (Tables S4, S6, S15-16).

\begin{tabular}{|c|c|c|c|c|}
\hline & $\begin{array}{l}\text { Chemical } \\
\text { compounds }\end{array}$ & CMD & Pathway to stream & Source nature \\
\hline \multicolumn{5}{|c|}{ Anthropogenic point sources: } \\
\hline Industrial discharge & Chloride & $316 \mathrm{~kg} \mathrm{Cl} / \mathrm{yr}$ & $\begin{array}{l}\text { Stream water } \\
\text { discharge }\end{array}$ & Continuous source \\
\hline $\begin{array}{l}\text { Urban activities } \\
\text { (road salting) }\end{array}$ & Sodium chloride & $\begin{array}{l}1,192 \mathrm{~kg} \mathrm{Cl} / \mathrm{yr} \\
728 \mathrm{~kg} \mathrm{Na} / \mathrm{yr}\end{array}$ & $\begin{array}{l}\text { Groundwater } \\
\text { discharge }\end{array}$ & Continuous source \\
\hline $\begin{array}{l}\text { Contaminated site } \\
\text { (Factory site, 1. entry) }\end{array}$ & $\begin{array}{l}\text { Chlorinated ethenes, } \\
\text { benzene, } \\
\text { pharmaceuticals }\end{array}$ & $\begin{array}{l}212 \mathrm{~kg} \mathrm{VC} / \mathrm{yr} \\
49 \mathrm{~kg} \text { benzene } / \mathrm{yr} \\
101 \mathrm{~kg} \\
\text { sulfanilamide } / \mathrm{yr}\end{array}$ & $\begin{array}{l}\text { Groundwater } \\
\text { discharge }\end{array}$ & Continuous source \\
\hline $\begin{array}{l}\text { Contaminated site } \\
\text { (Factory site, 2. entry) }\end{array}$ & Pharmaceuticals & $\begin{array}{l}44 \mathrm{~kg} \text { sulfanilamide/yr } \\
31 \mathrm{~kg} \mathrm{VC} / \mathrm{yr} \\
19 \mathrm{~kg} \text { benzene/yr }\end{array}$ & $\begin{array}{l}\text { Groundwater } \\
\text { discharge }\end{array}$ & Continuous source \\
\hline Fish farms & $\begin{array}{l}\text { Pharmaceuticals } \\
\text { (sulfonamides) }\end{array}$ & $8.9 \mathrm{~kg}$ sulfathiazole $/ \mathrm{yr}$ & $\begin{array}{l}\text { Stream water } \\
\text { discharge }\end{array}$ & $\begin{array}{l}\text { Presumable a variable } \\
\text { source }\end{array}$ \\
\hline \multicolumn{5}{|c|}{ Anthropogenic diffuse sources: } \\
\hline $\begin{array}{l}\text { Agricultural activities } \\
\text { (manure) }\end{array}$ & Copper, nickel, zinc & - & $\begin{array}{l}\text { Groundwater } \\
\text { discharge }\end{array}$ & Continuous source \\
\hline \multirow{2}{*}{$\begin{array}{l}\text { (manure, fertilizer) } \\
\text { (crop protection } \\
\text { spraying) }\end{array}$} & Nitrogen & - & $\begin{array}{l}\text { Atmospheric } \\
\text { deposition, surface } \\
\text { water run-off }\end{array}$ & $\begin{array}{l}\text { Continuous source with } \\
\text { periodic peaks due to } \\
\text { stormflow events }\end{array}$ \\
\hline & Pesticides & - & $\begin{array}{l}\text { Groundwater } \\
\text { discharge and } \\
\text { surface water }\end{array}$ & $\begin{array}{l}\text { Continuous with periodic } \\
\text { peaks in the discharge } \\
\text { due to seasonal spraying }\end{array}$ \\
\hline Urban activities & Pesticides & - & $\begin{array}{l}\text { Groundwater } \\
\text { discharge }\end{array}$ & Continuous source \\
\hline $\begin{array}{l}\text { Urban activities/ } \\
\text { traffic emission } \\
\text { Geogenic diffuse sour }\end{array}$ & Toluene & - & $\begin{array}{l}\text { Atmospheric } \\
\text { Deposition }\end{array}$ & Continuous source \\
\hline $\begin{array}{l}\text { A natural release of } \\
\text { trace metals }\end{array}$ & $\begin{array}{l}\text { Barium, copper, } \\
\text { nickel, zinc }\end{array}$ & & $\begin{array}{l}\text { Groundwater } \\
\text { discharge }\end{array}$ & Continuous source \\
\hline $\begin{array}{l}\text { Acidification of the } \\
\text { non-calcareous } \\
\text { aquifer }\end{array}$ & $\begin{array}{l}\text { Aluminum, copper, } \\
\text { nickel, zinc }\end{array}$ & & $\begin{array}{l}\text { Groundwater } \\
\text { discharge }\end{array}$ & Continuous source \\
\hline \multicolumn{5}{|l|}{ Geogenic point source: } \\
\hline Groundwater plume & Arsenic, nickel & - & $\begin{array}{l}\text { Groundwater } \\
\text { discharge }\end{array}$ & Continuous source \\
\hline
\end{tabular}

\subsubsection{Metals}

The dissolved iron (Fe) concentration in SW (Tables S4-5) was found to comply with the Danish 290 'moderate standard' for streams (>0.2 to $0.5 \mathrm{mg} / \mathrm{L}$; DCEE, 2012). The stable but elevated level throughout the stream corridor could be due to the local geochemistry of the upper aquifer, which has a naturally high content of Fe (DCEE, 2012). The overall pattern indicated that the HZ was more reduced in the urban stations, comprised of the upstream area of station 4, and stations 6 and 8 
Dissolved barium $(\mathrm{Ba})$, copper $(\mathrm{Cu})$, lead $(\mathrm{Pb})$, nickel $(\mathrm{Ni})$ and zinc $(\mathrm{Zn})$ in $\mathrm{SW}$ all exceeded the

Danish EQS in both campaigns (Apr and Aug 2014; Table 2, Tables S10-11) and the detected concentrations in the $\mathrm{HZ}$ were frequently even higher. The $\mathrm{SW}$ concentrations of $\mathrm{Ba}, \mathrm{Cu}, \mathrm{Ni}$ and $\mathrm{Zn}$ were, however, within the values typical for Danish groundwater (90\% quantile, Table 2) indicating the stream is groundwater-fed.

The combination of elevated aluminum (Al), $\mathrm{Cu}, \mathrm{Ni}$ and $\mathrm{Zn}$ concentrations (Table 2) could further indicate an acidification of the aquifer, as reported in a catchment study by Kjøller et al. (2004). They observed specifically an increased release of $\mathrm{Al}$ and $\mathrm{Ni}$; yet, $\mathrm{Cu}$ and $\mathrm{Zn}$ can also potentially be mobilized via acidification as reported by Edmund et al. (1992). Another potential source for the increased $\mathrm{Cu}$ and $\mathrm{Zn}$ concentrations in SW could be from the application of pig manure to agricultural fields, similar to the findings of Gräber et al. (2005) and Formentini et al. (2015). This is a growing source of concern in many countries, as it is used as a replacement for antibiotics and as growth promoters at pig farms (Gräber et al., 2005; Jondreville et al., 2003).

Table 2: Detected levels for the dissolved trace metals in Grindsted SW in 2014, Danish streams and groundwater in 20042012, as well as Danish EQS values for freshwater where relevant. All concentrations are in $\mu \mathrm{g} / \mathrm{L}$. Dashes indicate data is not available.

\begin{tabular}{|c|c|c|c|c|c|c|c|c|c|}
\hline \multirow{2}{*}{$\begin{array}{l}\text { Dissolved } \\
\text { trace } \\
\text { metals }\end{array}$} & \multicolumn{2}{|c|}{ Grindsted SW } & \multicolumn{2}{|l|}{$\begin{array}{l}\text { Danish } \\
\text { SW }^{1}\end{array}$} & \multicolumn{2}{|c|}{$\begin{array}{l}\text { Reference SW } \\
\text { Skjern stream }\end{array}$} & \multicolumn{2}{|c|}{$\begin{array}{l}\text { Danish } \\
\text { groundwater }{ }^{1}\end{array}$} & \multirow{2}{*}{$\begin{array}{l}\text { Danish EQS } \\
\text { (freshwater) }^{2}\end{array}$} \\
\hline & Median & $90 \%^{3}$ & Median & $90 \%^{3}$ & Median & $90 \%^{3}$ & Median & $90 \%^{3}$ & \\
\hline Aluminum & 48 & 64 & 0.79 & 1.5 & - & - & 2.20 & 12 & - \\
\hline Arsenic & $<1.3$ & & 0.73 & 2 & - & - & 0.54 & 3.40 & 4.3 \\
\hline Barium & 75 & 80 & 63 & 82 & - & - & 71 & 200 & $\begin{array}{l}9.3+15 \text { (natural } \\
\text { background level) }\end{array}$ \\
\hline Cadmium & $<1.3$ & & - & - & 0.034 & 0.040 & 0.011 & 0.16 & $\leq 0.08-0.25$ \\
\hline Copper & 2.3 & 4.3 & 1.1 & 2.5 & 0.95 & 1.5 & 0.41 & 4.50 & 1 (12 upper level) \\
\hline Chrome & $<1.3$ & & 0.30 & 0.61 & - & - & 0.34 & 0.88 & $\mathrm{Cr}$ (VI) 3.4, $\mathrm{Cr}$ (III) 4.9 \\
\hline Lead & 1.8 & 3.7 & 0.23 & 0.63 & 0.08 & 0.69 & 0.03 & 0.075 & 0.34 \\
\hline Nickel & 6.5 & 7.7 & 1.3 & 2.0 & 3.35 & 3.7 & 1.10 & 11 & $\begin{array}{l}2.3+0.82 \text { (natural } \\
\text { background level) }\end{array}$ \\
\hline Vanadium & $<1.3$ & & 0.48 & 0.92 & - & - & - & - & 4.1 \\
\hline Zinc & 14 & 22 & 4.2 & 14 & 8.9 & 18 & 3.10 & 41 & $\begin{array}{l}7.8+1.5 \text { (natural } \\
\text { background level) }\end{array}$ \\
\hline Mercury & $<0.2$ & & $<0.001$ & 0.0039 & $0.003-0$. & $(n=2)$ & $<0.001$ & 0.010 & 0.05 \\
\hline
\end{tabular}

${ }^{1}$ DCEE, 2015, median values from 2004-2012

${ }^{2}$ Danish EPA, 2010

${ }^{3} 90 \%$ quantile

The level of dissolved arsenic (As) in the stream was always below the Danish EQS. However, compared to typical Danish groundwater values, a notably high level for both As and Ni was 
observed in the HZ within the urban area (90\% quantile: Table 2, S10-11). This coincided with the stations where strongly reduced conditions were detected. The Fe-reduction process may, in addition to the dissolution of Fe(II), mobilize trace metals. It therefore indicates a secondary effect of the prevailing redox conditions and may be the main explanation for an increased geogenic release of As in the discharge area of the contaminant plume. Observations of arsenic in groundwater at the streambank further confirm elevated As in the core of the contaminant plume (data not shown). Similarly, Cozzarelli et al. (2016) reported increased As levels under strongly reduced conditions in a petroleum hydrocarbon plume.

In contrast, the mobility of $\mathrm{Ni}$ is not known to be affected by the redox conditions, but a relationship was observed between increased Ni concentrations and increased NVOC (Tables S4, S10-11), as also seen in landfill leachate-polluted groundwater by Christensen et al. (1996). The presence of dissolved humic acids has been shown to promote $\mathrm{Ni}$ solubility through complex formation, thereby removing the dissolved ions from the state of equilibrium with the sediment particle. This suggests geogenic processes related to the strongly reduced and carbon-rich factory plume as being responsible for the increased levels of As and Ni.

It should be noted that the metal content in the BS was very low compared to freshwater sediment benchmarks (US EPA, 2006) for chronic exposure using non-lethal endpoints for sensitive invertebrate species (Tables S12-13). Metals in BS were thus considered insignificant and not considered further.

\subsubsection{Chlorinated ethenes, BTEX,N and pharmaceuticals}

High concentrations of cis-DCE and VC $(2289$ - $4498 \mu \mathrm{g} / \mathrm{L})$ were detected in the HZ, covering a $50 \mathrm{~m}$ stretch, which was followed by an abrupt increase in SW concentration (from 0.4 to $6.4 \mu \mathrm{g}$ $\mathrm{VC} / \mathrm{L}$ ) that remained elevated far downstream (Fig. 3A-D). This strongly implies the main pathway for this contamination to enter the stream occurs via groundwater discharge. The recurring temporal pattern observed in the stream also indicates that the contaminant plume discharge is a significant and continuous source. A similar appearance in the stream was observed for the pharmaceutical compounds, e.g. sulfamethiazole and meprobamate (Fig. 3E-H). However, they were detected over 
346 a longer distance in the $\mathrm{HZ}$ (ca. $0.5 \mathrm{~km}$ ) in lower concentrations and in a more scattered spatial 347 pattern at stations 4, 6 and 8, which made the peak for SW less distinct. Based on the known 348 fingerprint of the factory plume, stations 4-8 thus comprise the main location for chemical input via 349 groundwater to the stream.

350 Benzene showed a pattern comparable to the degradation products of the chlorinated ethenes, 351 while toluene was detected in similar concentrations in both the SW and HZ (Tables S6-7) 352 throughout the stream corridor. The recurring pattern and constant level of toluene in the SW 353 suggests a diffuse source, e.g. atmospheric deposition from traffic emissions/urban activities in the 354 area, as also observed by Kenner et al. (2014).

355 The CMD estimated at the point of fully mixed conditions, i.e. at station 3 , are shown in Table 1 356 and S16 (1. entry). A small additional input of chlorinated ethenes, benzene and pharmaceuticals 357 was observed between stations 3 and 2 in the stream (Tables 1, S6). This input had a different 358 contaminant composition (Table S16, 2. entry) with a noticeable decrease in the discharge of 359 chlorinated ethenes compared to benzene and the pharmaceuticals. Here, the source could be a 360 plume originating from another part of the rather large factory site (Fig. 1). 

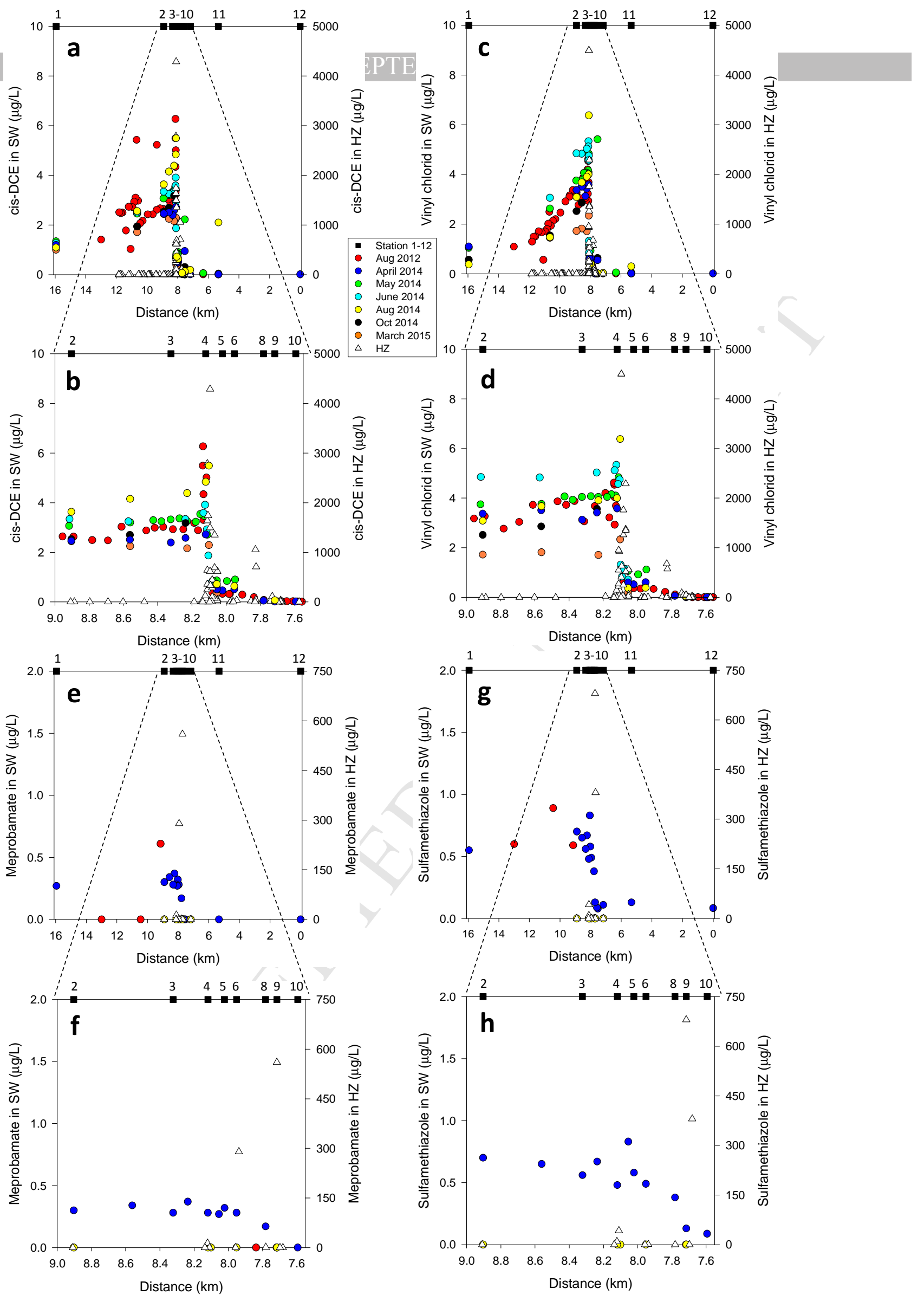

Fig. 3: The long term monitoring results for $\mathrm{SW}$ and $\mathrm{HZ}$ are shown for two chlorinated ethene metabolites, cis-DCE (a-b) and VC (c-d), and the pharmaceutical compounds meprobamate (e-f) and sulfamethiazole (g-h) for the period of Aug 2012 to Mar 2015. The locations of the twelve sampling stations (1-12) are presented at the top of the graphs. Note the scale can differ from figure to figure. 
farm, whereas sulfathiazole and sulfadiazine were additionally detected at station 11, just downstream of the $2^{\text {nd }}$ fish farm. Assuming fully mixed conditions at the two stations downstream of the fish farms, a small but significant contribution could be estimated (Tables 1, S16). The composition of this source can be distinguished from the factory plume via the composition of the sulfonamides. In the upper catchment where the fish farms are located, sulfamethiazole, sulfathiazole and sulfadiazine were present in equal amounts, while sulfamethiazole dominated the pharmaceutical input from the groundwater plume (Table S16). However, evaluating the stream corridor as a whole, it can be seen that most of the pharmaceutical contamination originates from the factory plume, leaving the input from the fish farms as only minor (Tables 1, S16).

The importance of dilution, degradation and volatilization on the in-stream fate of the groundwater-borne organic contaminants was examined from a point of fully mixed conditions (at station 3), to $7 \mathrm{~km}$ downstream from the mixing point (at station 1) (Fig. 1). The reduction in contaminant concentrations showed that, e.g. cis-DCE, VC and benzene were on average $63 \%$ lower than would be predicted due to dilution alone (Table S17), whereas the reduction in sulfonamide concentrations (sulfanilamide, sulfaguanidine, sulfamethazine) could be explained by dilution only (Table S17). The highly volatile compounds cis-DCE, VC and benzene can potentially be removed by volatilization and degradation. However, degradation is not likely due to the short retention time $(<20 \mathrm{hr})$ in addition to the stable molar ratio of the chlorinated ethenes detected in the SW, and constant stable carbon isotope fractionation throughout the stream stretch (Tables S18388 predominantly by dilution and volatilization. 

used in various fungicides and insecticides) and aminomethylphosphonic acid (AMPA, a metabolite of glyphosate, a widely used herbicide in both urban and agricultural settings; McKnight et al., 2015), were found only in the SW but at most stations, indicating they mainly originate from diffuse sources. 2,6-dichlorobenzamide (BAM, a metabolite of the herbicide dichlobenil, banned since 1997), however, was detected in both the HZ and SW at stations 4 and 8, which suggests an input via groundwater discharge from the previous use of dichlobenil in urban areas. Additional herbicides and insecticides (e.g. 4-chloro-2-methylphenol, metamitron, 2,6-dichlorophenol, dimethoate) were only detected in the $\mathrm{HZ}$ of the urban area. The presence of pesticides in the upper BS showed a similar pattern (Tables S12-13). The low concentrations detected in all three stream compartments indicates a minor impact overall coming from pesticides at the time of the two campaigns.

403

\section{Risk assessment, sources and contaminant mass discharge}

In order to estimate the effects of the various chemical compounds present in Grindsted stream, TU was calculated for the detected compounds and $\Sigma T U$ for the identified compound groups (Table 2). Overall the results revealed that the metals posed the highest predicted ecotoxic risk to the investigated stream corridor in both the SW and HZ compartments, while contaminants originating from groundwater plume(s) may be acting as an additional stress factor in the HZ in particular between stations 4 and 8 .

This interpretation is based on the predicted toxicological potential $(\log \Sigma T U)$ for the trace metals detected in both the SW and HZ, where it showed remarkably high values ranging from -1.78 to 0.37 (Table 2). This was mainly driven by the $\mathrm{Al}$ and $\mathrm{Cu}$ concentrations at all stations, while As, $\mathrm{Ni}$ and $\mathrm{Zn}$ also contributed to the elevated levels in the HZ. The $\log \Sigma \mathrm{TU}$ values in both compartments indicate a substantial potential toxic risk throughout the stream corridor (Table 2), according to both Liess et al. (2008, given threshold: $\log \Sigma T U \geq-3)$ and von der Ohe et al. (2004, threshold: $\log \Sigma T U \geq-$ 2). The diffuse geogenic sources of metals were therefore found to play a substantial role for the 
be enhanced locally due to the reduced conditions within the contaminant plume, leading to the increased mobilization of dissolved Fe and Mn.

Table 2: $\log \Sigma T U$ for metals, pesticides, chlorinated ethenes, BTEX, and pharmaceuticals detected in the three compartments (SW, HZ, PW(BS)) of Grindsted stream in Apr and Aug 2014. The log $\Sigma T U$ for a compartment is only shown when at least one value exceeded $\mathbf{- 3 . 0}$ at a station along the stream (see Tables S6-S13 for more details). Note that the total sum for log $\Sigma T U$ presents the sum of all five compound groups. The compound groups responsible for the dominant (potential) ecotoxic risk at each of the sampling stations are highlighted in bold. "<DL" indicates that all compounds in the group were below the detection limits.

\begin{tabular}{|c|c|c|c|c|c|c|c|c|c|c|c|c|c|}
\hline Apr & St.1 & St.2 & St.3 & \multicolumn{2}{|c|}{ St.4 } & St.5 & St.6 & St.7 & St.8 & St.9 & St.10 & St.11 & St.12 \\
\hline \multicolumn{14}{|l|}{ Metals } \\
\hline SW & -0.92 & -0.97 & -1.02 & \multicolumn{2}{|c|}{-0.72} & -1.03 & -0.81 & -1.00 & -1.17 & -0.92 & -1.12 & -0.92 & -0.85 \\
\hline $\mathrm{HZ}$ & -0.92 & -1.04 & -1.02 & \multicolumn{2}{|c|}{-1.45 to -1.02} & -1.10 & $\begin{array}{l}-1.52 \text { to } \\
-0.84\end{array}$ & -1.00 & $\begin{array}{l}-1.78 \text { to } \\
-1.17\end{array}$ & -0.92 & -1.12 & -0.92 & -0.85 \\
\hline \multicolumn{14}{|c|}{ Pesticides } \\
\hline $\mathrm{PW}(\mathrm{BS})^{\mathrm{a}}$ & $<\mathrm{DL}$ & $<\mathrm{DL}$ & -3.63 & \multicolumn{2}{|c|}{-4.54} & -4.16 & $<\mathrm{DL}$ & -2.38 & -2.86 & -3.98 & $<\mathrm{DL}$ & $<\mathrm{DL}$ & $<\mathrm{DL}$ \\
\hline \multicolumn{14}{|c|}{ Chlorinated ethenes } \\
\hline $\mathrm{HZ}$ & -4.59 & -4.10 & -4.13 & \multicolumn{2}{|c|}{-2.47 to $\mathbf{- 1 . 9 6}$} & -4.25 & $\begin{array}{l}-4.23 \text { to } \\
-3.16\end{array}$ & -4.25 & $\begin{array}{l}-3.43 \text { to } \\
\mathbf{- 3 . 1 4}\end{array}$ & -4.47 & $<\mathrm{DL}$ & $<\mathrm{DL}$ & $<\mathrm{DL}$ \\
\hline \multicolumn{14}{|l|}{ BTEX } \\
\hline $\mathrm{HZ}$ & -3.88 & -3.61 & -3.83 & \multicolumn{2}{|c|}{-3.76 to $\mathbf{- 1 . 7 0}$} & -3.92 & $\begin{array}{l}-3.41 \text { to } \\
\mathbf{- 2 . 8 0}\end{array}$ & -3.98 & $\begin{array}{l}-4.15 \text { to } \\
\mathbf{- 2 . 9 8}\end{array}$ & -4.07 & -4.15 & -4.27 & -2.81 \\
\hline \multicolumn{14}{|c|}{ Pharmaceuticals } \\
\hline $\mathrm{HZ}$ & -2.52 & -2.49 & -2.53 & \multicolumn{2}{|c|}{-0.64} & -2.48 & 0.47 & -2.76 & 0.76 & -5.22 & -4.99 & -4.91 & -5.04 \\
\hline \multicolumn{14}{|c|}{ Total sum of $\log \Sigma T U$} \\
\hline SW & -0.91 & -0.95 & -1.00 & \multirow{2}{*}{\multicolumn{2}{|c|}{$\begin{array}{c}-0.71 \\
-0.58 \text { to } 0.45 \\
\end{array}$}} & -1.01 & -0.80 & -0.99 & -1.17 & -0.92 & -1.12 & -0.92 & -0.85 \\
\hline $\mathrm{HZ}$ & -0.91 & -1.02 & -1.01 & & & -1.08 & 0.47 & -0.99 & 0.77 & -0.92 & -1.12 & -0.92 & -0.85 \\
\hline Aug & & St.2 & & $\begin{array}{l}\text { St. } \\
\text { 4DS }\end{array}$ & $\begin{array}{l}\text { St. } \\
\text { 4US }\end{array}$ & & St.6 & & St.8 & & St.10 & & \\
\hline \multicolumn{14}{|l|}{ Metals } \\
\hline SW & & -0.87 & & -1.04 & -0.83 & & -0.95 & & -0.99 & & -0.88 & & \\
\hline $\mathrm{HZ}$ & & -0.29 & & -1.09 & -0.84 & & -0.45 & & -0.72 & & -0.86 & & \\
\hline \multicolumn{14}{|c|}{ Chlorinated ethenes } \\
\hline $\mathrm{HZ}$ & & -6.12 & & -3.51 & -1.24 & & -3.60 & & -4.42 & & -5.46 & & \\
\hline \multicolumn{14}{|c|}{ Pharmaceuticals } \\
\hline $\mathrm{HZ}$ & & $<\mathrm{DL}$ & & -2.61 & -0.48 & & -4.61 & & -3.14 & & -3.38 & & \\
\hline \multicolumn{14}{|c|}{ Total sum of $\log \Sigma T U$} \\
\hline SW & & -0.87 & & -1.04 & -0.83 & & -0.95 & & -0.99 & & -0.87 & & \\
\hline $\mathrm{HZ}$ & & -0.29 & & -1.08 & -0.27 & & -0.45 & & -0.72 & & -0.86 & & \\
\hline
\end{tabular}

$428{ }^{\mathrm{a}} \mathrm{PW}(\mathrm{BS})$ is the pore water calculated based on the be sediment concentrations.

429 The presence of the groundwater-borne organic contaminant groups (chlorinated ethenes, BTEX,

430 pharmaceuticals) only showed significant potential toxicity in the $\mathrm{HZ}$ at stations 4, 6 and 8 in Apr

431 (Table 2), whereas in Aug it was reduced to only the smaller area of station 4 (4US). This risk was

432 found to be quite spatially limited, e.g. impact zones were localized over very short distances.

433 Nonetheless, once they enter the SW, the elevated levels of contaminants were found to persist

434 more than $7 \mathrm{~km}$ downstream of the primary discharge zones and in the case of VC (a known human 
carcinogen), these concentrations were well above the Danish EQS (0.05 $\mu \mathrm{g} \mathrm{VC/L})$. Moreover, a recent study has documented sub-lethal effects of VC on D. magna (10-d chronic exposure tests) at the gene, cellular and life-history levels at concentrations down to $0.1 \mu \mathrm{g} \mathrm{VC} / \mathrm{L}$ (Houde et al., 2015). The potential impacts in the SW could thus extend over much greater distances compared to the risk in the $\mathrm{HZ}$.

The input from the fish farms and presence of toluene in SW, on the other hand, did not show any potential risk to the stream system. The detected pesticides also posed no risk (-3.65 to -6.14$)$ in either campaign, except for the BS(PW) at the two urban stations 7 and $8(-2.38$ and -2.86 , respectively). This toxicity was driven by the presence of the hexachlorocyclohexane isomers (alfa, beta, delta).

The high input of chloride (app. 1,200 kg Cl/yr) leading to stable levels in the stream (25-35 mg $\mathrm{Cl} / \mathrm{L}$ ) throughout the investigated corridor were still well below the EQS value stated by the European EPA (120 mg Cl/L; Danish EPA, 2013). Even the highest concentrations, detected in the $\mathrm{HZ}$ (232 $\mathrm{mg} \mathrm{Cl/L}$ ), were far below acute toxicity levels documented to affect benthic invertebrates in freshwater streams similar to Grindsted (3,172-4,154 mg Cl/L; Elphick et al., 2011). The input was therefore not considered to pose a risk to the stream.

The application of a combination of in-stream CMD, threshold values (EQS) and TU to assess the chemical quality of $\mathrm{SW}, \mathrm{HZ}$ and BS seems promising. We identified the sources of the contamination and were in many cases also able to quantify the actual CMD. The geogenic origin of metals and the associated risk suggests that metals should be considered in the risk assessment of streams in particular for mixed land use systems. Surprisingly pesticides were of less importance, while the significant impact of xenobiotic compounds from the factory plume was striking. CMD in the range of several $100 \mathrm{~kg} / \mathrm{yr}$ for chlorinated ethenes and pharmaceutical compounds impacting the stream for several kilometers deserves attention and is valuable information for the focus of future remedial actions. 


\section{Perspectives}

Traditionally, the monitoring of streams has been focused on SW concentrations as debated in

Fairbairn et al. (2015) and much focus has been on the general water quality and the risk for eutrophication (McKnight et al., 2012). We consider if the actual risk for such systems has been underestimated, particularly if the identification of the actual risk drivers was based on a narrow, single compound group approach (e.g. nutrients, BOD) looking only into the impact of one or two stream compartments. Taking Grindsted stream as an example, the general water quality, nutrients and oxygen demand are all indicative of a healthy stream, while the actual results, including metals and organic xenobiotic compounds, show the opposite. Thus, we recommend a much broader focus including heavy metals and organic xenobiotics in multiple compartments in future monitoring programs.

Fortunately, many recent studies address multiple stream compartments (Kim and Carlson, 2006; Beketov et al., 2013) or multiple compounds (Gerner et al., 2017; Yu et al., 2014). However, it seems that only a few studies included geogenic sources, $\mathrm{HZ}$ and the groundwater pathway in their investigations (Naik and Hammerschmidt, 2011; Roy and Bickerton, 2012; McKnight et al., 2015). The groundwater pathway and geogenic sources require special attention for metals, where mobilization of $\mathrm{Fe}$ and As in strongly reduced contaminant plumes, release due to acidification, or increased mobility of $\mathrm{Ni}$ in carbon-rich environments may add additional complexity.

Investigations in mixed land use systems have also been reported including multiple contaminants and compartments (e.g. Fairbairn et al., 2015; Nazeer et al., 2014), but often the link to actual sources is missing (e.g. Kuzmanovic et al., 2016; Castro-Catalá et al., 2016). Our findings suggest that it is advisable in future studies to address mixed land use systems holistically including the CMD approach. The quantification of CMD from stream concentrations is very useful for an initial ranking of the identified sources and will be able to guide future remedial actions for contaminated sites. This will be crucial for the management of the stream at the catchment scale using e.g. river basin management plans in order to fulfill the requirements of the WFD and in general to improve the chemical quality in streams. 


\section{Conclusion}

This study aimed to assess chemical stream quality in mixed land use systems by combining the evaluation of the chemical quality and predicted toxicity potential for the three stream compartments (SW, HZ, BS) using the CMD framework, the latter particularly to quantify the potential impact from the identified anthropogenic point sources in catchments. The method developed in this study was tested and yielded promising results at a 16-km stream corridor of the Grindsted stream (Denmark).

The groundwater-fed stream was substantially impaired by both geogenic and anthropogenic sources of metals throughout the investigated stream corridor, reaching critical toxic potential levels in both the SW and HZ compartments. Notably, the impairment was quite uniformly distributed, which made the impact of additional chemical stressors especially in the HZ more pronounced. The inflow of a contaminated groundwater plume gave an unexpectedly manifold impact to the chemical quality, particularly in the HZ. We suggest that the highly localized "toxic potential risk zones" were additionally impacted by the strongly reduced water - characterized by high concentrations of $\mathrm{Fe}$ - created by the degradation of xenobiotic compounds, leading additionally to the release of arsenic.

The methodology applied in this study is thus capable of providing a holistic picture of the chemical quality in a stream, which includes the ability to integrate stressor interactions not ordinarily evaluated together (i.e. organic and inorganic contaminants). Moreover, it points to the compartments that may represent a potential hazard to the stream ecosystem, and gives an indication of the gravity of the situation. We think that the method will be suitable for many mixed land use systems, and that the complexity of the chemical stressors will be misleadingly evaluated (i.e. underestimated) if only a single compound group or compartment are covered.

\section{Acknowledgements}

This study was supported by the research project GEOCON, Advancing GEOlogical, geophysical and CONtaminant monitoring technologies for contaminated site investigation (contract no. 130500004B). Funding was provided by Innovation Foundation Denmark, the Danish Environmental 
Associate Professor Emeritus Kresten Ole Kusk, DTU Environment, supported the estimation of the

predicted acute toxicity of the pharmaceutical compounds. Finally, we are grateful to Professor

Daniel Hunkeler, University of Neuchatel, who provided the compound specific stable carbon

isotope analysis.

\section{References}

Aisopou, A., Bjerg, P.L., Sonne, A.T., Balbarini, N., Rosenberg, L., Binning, P.J., 2015. Dilution and volatilization of groundwater contaminant discharges in streams. J. Contam. Hydrol. 172 (2015), 71-83.

Balbarini, N., Boon, W.M., Nicolajsen, E., Nordbotten, J.M., Bjerg, P.L., Binning, P.J., 2017. A numerical 3-D model of the influence of meanders on groundwater discharge to a gaining stream in an unconfined sandy aquifer. J. Hydrology. Submitted.

Beketov, M.A. and Liess, M., 2012. Ecotoxicology and macroecology - Time for integration. Environ. Pollut. 162 (2012), 247-254.

Beketov, M.A., Kefford, B.J., Schäfer, R.B., Liess, M., 2013. Pesticides reduce regional biodiversity of stream invertebrates. PNAS 110 (27), 11039-11043.

Billund Vand A/S, 2016: pers. comm. Bjarne Bro, Grindsted Landevej 40, 7200 Grindsted, Denmark (05/04/2016).

Castro-Catalá, N., Kuzmanovic, M., Roig, N., Sierra, J., Ginebreda, A., Barceló, D., Pérez, S., Petrovic, M., Picó, Schuhmacher, M., Muñoz, I., 2016. Ecotoxicity of sediments in rivers: Invertebrate community, toxicity bioassay and the toxic unit approach as complementary assessment tools. Sci. Total Environ. 540 (2016), 297-306.

Christensen, J.B., Jensen, D.L., Christensen, T.H., 1996. Effect of dissolved organic carbon on the mobility of cadmium, nickel and zinc in leachate polluted groundwater. Water Res. 30 (12), 30373049.

Christensen, T.H., Bjerg, P.L., Banwart, S.A., Jakobsen, R., Heron, G., Albrechtsen, H-J., 2000. Characterization of redox conditions in groundwater contaminant plumes. J. Contam. Hydrol. 45 (2001), 165-241.

Cozzarelli, M., Schreiber, M.E., Erickson, M.L., Ziegler, B.A, 2016. Arsenic Cycling in Hydrocarbon Plumes: Secondary Effects of natural Attenuation. Groundwater 54 (1), 35-45.

Cooper, C. A., Mayer, P. M., Faulkner, B.R., 2014. Effects of road salts on groundwater and surface water dynamics of sodium and chloride in an urban restored stream. Biogeochemistry 121, 149166.

DCEE, 2012, Danish Centre for Environment and Energy. Streams 2011. NOVANA (in Danish). Aarhus University DCE - National Center of Environment and Energy. Report no. 32.

DCEE, 2015, Danish Centre for Environment and Energy. Xenobiotic compounds and metals in surface waters. NOVANA (in Danish). State and development 2004-2012.

Danish EPA, 2010. The consolidation Act regarding environmental quality demands for surface waters and discharge of contamination to streams, lakes and sea (in Danish). BEK no. 1022 (25/08/2010).

Danish EPA, 2013. Cumulative assessment of discharge of metals and chloride from Arla's sewage works in relation to EQS values for freshwater in the Skjern stream system (in Danish). Background minutes regarding chloride, Appendix D.

DANMAP 2015. Use of antimicrobial agents and occurrence of antimicrobial resistance in bacteria from food animals, foods and humans in Denmark. ISSN 1600-2032.

Davis, J., Sim, L., Chambers, J., 2010. Multiple stressors and regime shifts in shallow aquatic ecosystems in antipodean landscapes. Freshwater Biol. 55 (Suppl. 1), 5-18. 
Di Toro, D.M., Hansen, D.J., Berry, W.J., Swartz, R.C., Cowan, C.E., Pavlou, S.P., Allen, H.E., Thomas, N.A., Paquin, P.R., 1991. Technical basis for establishing sediment quality criteria for nonionic organic chemicals using equilibrium partitioning. Environ. Toxicol. Chem. 10, 15411583.

Ding, J., Jiang, Y., Liu, Q., Hou, Z., Liao, J., Fu, L., Peng, Q., 2016. Influences of the land use pattern on water quality in low-order streams of the Dongjiang River basin, China: A multi-scale analysis. Sci. Total Environ. 551-552 (2016), 205-216.

EC, European Commission, Environment 2017: http://ec.europa.eu/environment/water/waterframework/index_en.html, accessed: 27/03/2017)

Edmunds, W.M., Kinniburgh, D.G., Moss, P.D., 1992. Trace metals in interstitial waters from sandstones: acidic inputs to shallow groundwaters. Environ. Pollut. 77 (1992), 129-141.

Elphick, J.R.F., Bergh, K.D., Bailey, H.C., 2010. Chronic toxicity of chloride to freshwater species: effects of hardness and implications for water quality guidelines. Environ. Toxicol. Chem. 30 (1), 239-246.

EQS, Environment Quality Standards Directive 2008/105/EC, December, 2008. Available at: http://eur-lex.europa.eu/LexUriServ/LexUriServ.do?uri=OJ:L:2008:348:0084:0097:en:PDF

Fairbairn, D.J., Karpuzcu, M.E., Arnold, W.A., Barber, B.L., Kaufenberg, E.F., Koskinen, W.C., Novak, P.J., Rice, P.J., Swackhamer, D.L., 2015. Sediment-water distribution of contaminants of emerging concern in mixed use watershed. Sci. Total Environ. 505(2015), 896-904.

Fausch, K.D., Baxter, C.V., Murakami, M., 2010. Multiple stressors in north temperate streams: lessons from linked forest-stream ecosystems in northern Japan. Freshwater Biol. 55 (Suppl. 1), 120-134.

Formentini, T.A., Mallmann, F.J.K., Pinheiro, A., Fernandes, C.V.S., Bender, M.A., Milton da Veiga, Rheinheimer dos Santos, D., Doelsch, E., 2015. Copper and zinc accumulation and fractionation in a clayey Hapludox soil subject to long-term pig slurry application. Sci. Total Environ. 536 (2015), 831-839.

Gerner, N.V., Koné, M., Ross, M.S., Pereira, A., Ulrich, A.C., Martin, J.W., Liess, M., 2017. Stream invertebrate community structure of Canadian oil sands development is linked to concentration of bitumen-derived contaminants. Sci. Total Environ. 575 (2017), 1005-1013.

Gräber I., Hansen J.F., Olesen S.E., Petersen J., Østergaard H.S., Krogh L., 2005. Accumulation of Cobber and Zinc in Danish Agricultural Soils in Intensive Pig Production Areas. Danish J. Geography 105 (2), 15-22.

Heron, G., Bjerg, P.L., Gravesen, P., Ludvigsen, L., Christensen, T.H., 1998. Geology and sediment geochemistry of a landfill leachate contaminated aquifer (Grindsted, Denmark). J. Contam. Hydrol. 29 (1998), 301-317.

Holm, J.V., Rügge, K., Bjerg, P.L., Christensen, T.H., 1995. Occurrence and Distribution of Pharmaceutical Organic Compounds in the Groundwater Downgradient of a Landfill (Grindsted, Denmark). Environ. Sci. Technol. 29 (5), 1415-1420.

Houde, M., Douville, M., Gagnon, P., Sproull, J., Cloutier, F., 2015. Exposure of Daphnia magna to trichloroethylene (TCE) and vinyl chloride (VC): Evaluation of gene transcription, cellular activity, and life-history parameters. Ecotoxicol. Environ. Saf. 116 (2015), 10-18.

Hunkeler, D., Abe, Y., Broholm, M.M., Jeannottat, S., Westergaard, C., Jacobsen, C.S., Aravena, R., Bjerg, P.L., 2011. Assessing chlorinated ethene degradation in a large scale contaminant plume by dual carbon-chlorine isotope analysis and quantitative PCR. J. Contam. Hydrol. 119 (2011), 69-79.

Jansson, Ch., Krueger, J., 2010. Multiresidue analysis of 95 pesticides at low nanogram/liter levels in surface waters using online preconcentration and high performance liquid chromatography/ tandem mass spectrometry. J. AOAC Int. 93 (6), 1732-1747.

Jondreville, C., Revy, P.S., Dourmad, J.Y., 2003. Dietary means to better control the environmental impact of copper and zinc by pigs from weaning to slaughter. Livestock Production Science 84 (2003), 147-156.

Kenner, S.J., Bender, D.A., Pankow, J.F., Zogorski, J.S., 2014. The atmosphere can be a source of certain water soluble volatile organic compounds in urban streams. J. Am. Water Resour. Assoc. 50 (5), 1124-1137. 
Kim, S., Carlson, K., 2006. Occurrence of ionophore antibiotics in water and sediments of a mixedlandscape watershed. Water Res. 40 (2006), 2549-2560.

Kjeldsen, P., Grundtvig, Aa., Winther, P., Andersen,SJ.S.,P1998: Characterization of an old municipal landfill (Grindsted, Denmark) as a groundwater pollution source: Landfill history and leachate compostition. Waste Manage. Res, 16 (1), 3-13.

Kjøller, C., Postma, D., Larsen, F., 2004. Groundwater Acidification and Mobilization of Trace Metals in Sandy Aquifer. Environ. Sci. Technol. 38, 2829-2835.

Kuzmanovic, M., López-Doval, J.C., De Castro-Català, N., Guasch, H., Petrović, M., Muñoz, I., Ginebreda, A., Barceló, D., 2016. Ecotoxicological risk assessment of chemical pollution in four Iberian river basins and its relationship with the aquatic macroinvertebrate community status. Sci. Total Environ. 540 (2016), 324-333.

Liess, M., Schäfer, R.B., Schriever, C.A., 2008. The footprint of pesticide stress in communities Species traits reveal community effects of toxicants. Sci. Total Environ. 406 (2008), 484-490.

McKnight, U.S., Rasmussen, J.J., Kronvang, B., Bjerg, P.L., Binning P.J., 2012. Integrated assessment of the impact of chemical stressors on surface water ecosystems. Sci. Total Environ. 427-428 (2012), 319-331.

McKnight, U.S., Rasmussen, J.J., Kronvang, B., Binning, P. J., Bjerg, P. L., 2015. Sources, occurrence and predicted aquatic impact of legacy and contemporary pesticides in streams. Environ. Pollut. 200 (2015), 64-76.

MEF, Ministry of Environment and Food of Denmark, 2016. Pers. comm. Henning Christensen, Strandgade 29, 1401 Copenhagen K, Denmark (03/05/2016).

Naik, A.P., Hammerschmidt, C.R., 2011. Mercury and trace metal partitioning and fluxes in suburban Southwest Ohio watersheds. Water Res. 45 (2011), 5151-5160.

Nazeer, S., Hashmi, M.Z., Malik, R.N., 2014. Heavy metals distribution, risk assessment and water quality characterization by water quality index of the River Soan, Pakistan. Ecol. Indic. 43 (2014), 262-270.

Newell, C. J.; Farhat, S. K.; Adamson, D. T., 2011. Contaminant plume classification system based on mass discharge. Ground Water 49 (6), 6914-919.

Nielsen, M.Æ., Carlson, B.B., Bjerg, P.L., Pedersen, J.K., Christensen, T.H., 1998. Sources for inorganic compounds in groundwater - including old landfills (in Danish). Vand \& Jord 1, 31-35.

Nielsen, S.S., Tuxen, N., Frimodt, O., P.L., Sonne, A.Th., Binning, P.J., Fjordbøge, A.S., Aabling, J. 2014. Risk assessment of surface water impacted by point source related contaminated groundwater (in Danish). Danish EPA, project no. 1575.

Petersen, M.F., 2012. Quantification and risk assessment of continuous micropollutant mass discharge from multiple sources to a gaining stream at the catchment scale. Master thesis, DTU Environment, Technical University of Denmark.

Rasmussen, J.J., Wiberg-Larsen, P., Baattrup-Pedersen, A., Cedergreen, N., McKnight, U.S., Kreuger, J., Jacobsen, D., Kristensen, E.A., Friberg, N., 2015. The legacy of pesticide pollution: An overlooked factor in current risk assessments of freshwater systems. Water Res. 84 (2015), 2532.

Rasmussen, J.J., McKnight, U.S., Sonne, A.Th., Wiberg-Larsen, P., Bjerg, P.L., 2016. Legacy of a Chemical Factory Site: Contaminated Groundwater Impacts Stream Macroinvertebrates. Arch. Environ. Contam. Toxicol. 70, 219-230.

Roy, J.W., Bickerton, G., 2012. Toxic Groundwater Contaminants: An Overlooked Contributor to Urban Stream Syndrome? Environ. Sci. Technol. 46, 729-736.

Rügge, K., Bjerg, P. L., Christensen, T. H., 1995. Distribution of organic compounds from municipal solid waste in the groundwater downgradient of a landfill (Grindsted, Denmark). Environ. Sci. Technol. 29 (5), 1395-1400.

Schwarzenbach, R.P., Escher, B.I., Fenner, K., Hofstetter, T.B., Johnson, C.A, Urs von Gunten, Wehrli, B., 2006. The Challenge of Micropollutants in Aquatic Systems. Science 313, 1072-1077. Stutter, M.I., Langan, S.J., Demars, B.O.L., 2007. River sediments provide a link between catchment pressures and ecological status in a mixed land use Scottish River system. Water Research 41, 2803-2815. 
669 Tomlin, C.D.S., 2001. The Pesticide Manual, a World Compendium. Farnham, Surrey, UK: Crop 670 Protection Publications.

671 US EPA, 2006. Available at: https://www.epa.gov/risk/freshwater-screening-benchmarks

672 van der Kooij, L.A., Van De Meent, D., Van Leeuwen, C.J., Bruggeman, W.A., 1991. Deriving 673 quality criteria for water and sediment from the results of aquatic toxicity tests and product 674 standards: application of the equilibrium partitioning method. Water Res. 25 (6), 697-705.

675 von der Ohe, P.C., Liess, M., 2004. Relative sensitivity distribution of aquatic invertebrates to 676 organic and metal compounds. Environ. Toxicol. Chem. 23 (1), 150-156.

677 Yu, S., Wu, Q., Li, Q., et al., 2014. Anthropogenic land uses elevated metal levels in stream water 678 in an urbanizing watershed. Sci. Total Environ 488-489 (2014), 61-69. 


\section{Highlights}

- A methodology to determine multiple stressor impact has been developed for streams

- Risk assessment of organic and inorganic chemicals in mixed land use systems

- Integrated evaluation of stream water, hyporheic zone and bed sediment is proposed

- A contaminant mass discharge framework can identify key sources and risk drivers

- Contaminated sites with substantial plumes may pose a risk to stream water quality 